\title{
Impact of Microfinance on Poverty: Qualitative Analysis for Grameen Bank Borrowers
}

\author{
Mohammad Aslam ${ }^{1}$, Senthil Kumar ${ }^{1} \&$ Shahryar Sorooshian ${ }^{2}$ \\ ${ }^{1}$ Faculty of Industrial Management, Universiti Malaysia Pahang, Pahang, Malaysia \\ ${ }^{2}$ Department of business administration, University of Gothenburg, Gothenburg, Sweden \\ Correspondence: Mohammad Aslam, Faculty of Industrial Management, Universiti Malaysia Pahang, Gambang \\ Kuantan 26300, Pahang, Malaysia. Tel: 1-2346-2861.
}

Received: September 11, 2019

Accepted: October 4, 2019

Online Published: October 17, 2019

doi:10.5430/ijfr.v11n1p49

URL: https://doi.org/10.5430/ijfr.v11n1p49

\begin{abstract}
Poverty is economic, social, political and even moral issue all over the world. Microfinance has been designed to eliminate poverty and may help marginal people to materialize their dreams. Microfinance has been formalized primarily in Bangladesh with this concept. Grameen Bank (GB) has been serving large number of people below poverty level here. Initially, microfinance institutions have been supported by the Government or Donor assuming its positive impact on borrowers. However, ambiguous impacts have been reported in several studies that make microfinance questionable. Therefore, this study intent to measure the impact of microfinance on GB borrowers through the process of qualitative changes in borrowers lives. The process has been measured by some case studies for participant and non-participant borrowers using Modified Household Economic Portfolio Model (M - HEPM). Our qualitative analysis shows that microfinance makes positive changes in the process of borrowers lives observed through financial and activity diaries of the borrowers.
\end{abstract}

Keywords: microfinance impact, poverty alleviation, qualitative analysis, modified household economic portfolio model

\section{Introduction}

The welfare impact on borrowers will be shaping the success story of microfinance. The borrowers might be benefited economically or socially or both. The fund providers require identifying the exact performance of microfinance through welfare impact on borrowers as they have invested money. They want an acceptable or good return from their investment. Khalily (2004) pointed out that there were two recognizable impact on the borrowers for microfinance. One is intermediate outcome and the other one is end outcome. The positive intermediate impact could happen through borrowers' consumption, nutrition intake, income, expenditure, wealth accumulation, kid education, savings, employment etc. The final impact could happen when borrowers got rid of poverty. As a whole, the impact will address the borrowers in three aspects such as impact on their businesses, households and individual lives. The more the microfinance brings positive changes or impacts, the more successful is the microfinance program with good performance. However, these positive changes have to done through getting involved in small businesses or some other activities that generate incomes for them. Islam (2007) identified that with the small amount of loan, the borrowers can buy small merchandise or raw materials or high yielding crops that increase their production and ultimately increase their income.

Microfinance impact can be evaluated in both quantitative and qualitative ways. Both types can answer the research questions asked in a specific study. However, mixed method combining qualitative with quantitative could be significant complement to impact assessments based on rather quantitative analysis only. Many qualitative ways are available with their respective own research domains. Alternative ways producing qualitative data usually engage open-ended styles that do not rely on prearranged answers from respondents being questioned. In qualitative studies, series of ways like focus group discussion, interviews with respondents, observing histories etc. can be used for gathering required data and information. Different ethnographic and observational assessments can be included as well. The derived results from qualitative studies may not be statistically representative like the case of quantitative studies. Therefore, they may not representable or generalizable but useful to understand outcome very clearly (Gertler, Martinez, Premand, Rawlings and Vermeersch, 2016). In this study, we intent to use qualitative aspect of the 
impact issues on GB borrowers through financial and activity diaries. It will give more insight of how the processes of welfare are being changed over the time among GB borrowers by microfinance. The borrowers' cash flow and activities have been recorded and analyzed for deep insight of understanding microfinance impact assessment.

The rest portion of the work will be presented as first giving the overview about impact studies of microfinance including theoretical framework and impact assessment issues. Then, it presents the qualitative impact assessment methodology and analysis followed by conclusion.

\section{Impact Studies of Microfinance}

Several researchers studied the impact of microfinance in different studies. Khandker (1998) studied 1800 borrowers in 86 villages in Bangladesh and got evidence of positive changes by different variables like consumption, income, expenditure, wealth accumulation, savings, employment etc. He also concluded that about five percent of the borrowers got rid of poverty by their respective category per year. Other researchers like Hashemi, Schuler, and Riley (1996), Husain (1998) found similar nature positive findings for the impact of microfinance in Bangladesh. All the authors here concluded that microfinance provided the better life for the poor people and lead them at least reduction of poverty or sometimes out of poverty.

The microfinance loans in many cases are used for borrowers' consumption rather than investment in the business. Here occurs the question of using the fund for intended purpose and use it efficiently and effectively. The more efficiently, borrower can use the loans, the more impact will prevail. MacIsaac (1997) pointed out that impact on borrowers was less when they do not invest the microfinance in income generating activities rather they consume the fund for personal purpose. The better-off clients participate in revenue producing activities but the worse-off clients consume the microfinance loan. Furthermore, Dunn and Arbuckle (2001a) pointed out that microfinance also indirectly make impact on household welfare besides its direct impact on microenterprise business. The household welfare is in household level like food consumption, housing quality etc.

Several other studies in Bangladesh done by Pitt and Khandker (1998), Zaman (1999), Khandker (2005) found that there was positive impact on borrowers' food expenditure, other consumption and kid's education. However, the impact findings are not similar in all studied countries. A study done by Dunn and Arbuckle (2001a) in Peru found increased income on household and increased consumption on food but not increased expense on kid education and domestic appliance. Both Mosley (2001) in Bolivia and Coleman (2002) in Thailand documented that relatively well-off borrowers enjoyed higher welfare changes than poor borrowers through using microfinance fund. Unfortunately, some negative impacts of microfinance were documented as well. Islam (2007) found that when borrowers borrowed from other informal lenders (often quoted as loan shark) to pay back the existing credit from microfinance, it made worse-off impact on the respective borrowers. Some studies found that microfinance in not working as has been intended and it has lost its mission (Duvendack et al., 2011; Hickel, 2015). They argued that microfinance merely creates poverty worse. Because many clients divert microcredit pay for basic amenities rather than invest in business. This makes their businesses either stop or fail that consequently dives them into further loan. For instance, about ninety-four percent of all microfinance loans have been used for consumption in South Africa (TRT.World, 2017). This ultimately reveals borrowers are not generating new revenue with the original loan. Consequently, they need to receive another loan to pay off existing loan and so forth. This plunge them into deep down more debt. Even in some cases, they have found themselves caught up in a dangerous cycle of death like committing suicide (Taylor, 2011). However, microfinance can serve as a useful instrument for the financially no served or underserved marginalized people when used appropriately. In both the ways, microfinance appears as a significant issue in the financial kingdom. If it is used appropriately, it can be an influential instrument for poverty alleviation (Cautero, 2019).

\subsection{Household Economic Portfolio Model (HEPM)}

The fungibility problem in assessing microfinance performance has more weight and importance than selection bias problem and endogeneity problem. But this problem can be resolved through Household Economic Portfolio Model (HEPM) model suggested by Assessing the Impact of Microenterprise Services (AIMS) (Khalily, 2004). The prime aspect of the HEPM framework is to escape overrating one specific characteristic of the client welfare. Therefore, HEPM suggested that microfinance impact should be studied on three separate perspective of client welfare such as borrowers' Enterprise or Business Perspective, Household or Family Perspective and Individual or Personal Perspective. Chen and Dunn (1996) suggested the HEPM framework based on their study. The component of the household resources in the HEPM framework belongs to the household comprises human household resource (time, labor and skill), physical household resource (land, building, tools \& equipment and raw materials) and financial household resource (cash and cash equivalents). 
All previously mentioned resources might be belonging either collectively or individually to the respective members of concerned household. The fund might come from either an informal or a formal organization or even from societal linkage. Having obtained fund from microfinance institute, there will be some initiatives do some household activities such as production household activities (income producing activity, household maintenance activity and outdoor activity), consumption household activities (basic amenities together with ceremonies and amusements), investment household activities (real property, productive assets, physical storage of wealth, human resource development through education and training). The income produced from these initiatives will flow into the domestic properties. The HEPM framework comes into effect by considering all perspectives of the borrower's domestic activities. The HEPM framework proposes that because each component is interrelated with each other, a microfinance impact assessment study should be carried out on all components such as microenterprise, household and individual (Please see Figure 1).

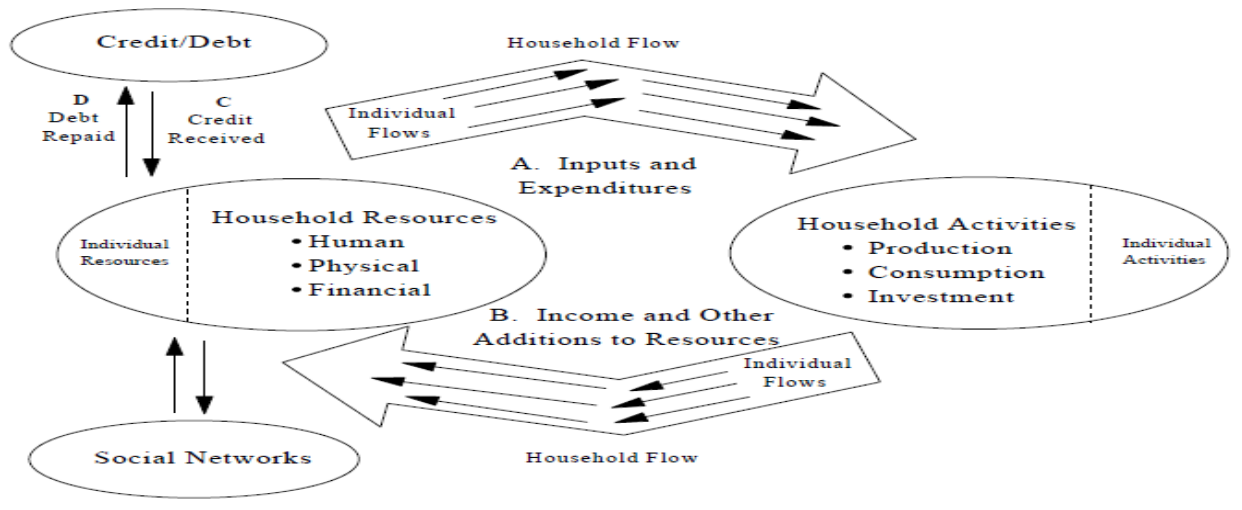

Figure 1. Conceptual model of household economic portfolio (Chen and Dunn, 1996)

\subsection{Modified Household Economic Portfolio Model (M - HEPM)}

HEPM is a complex model and has some limitations. Many researchers who quoted this model have labelled it as a difficult appraisal model that offers a fuller image for the impact of microfinance (Al Mamun, Abdul Wahab, \& Malarvizhi, 2011; Al Mamun, Abdul Wahab, \& Malarvizhi, 2010; Gobezie \& Garber, 2007; Hulme, 1997, 2000; Jacobsen, Marshak, Ofori-Adjei, \& Kembabazi, 2006). Hulme (1997) pointed out major application restrictions of this model like complexity in experiment, higher cost requirement, sophisticated analytical skills and time consuming.

Dunn and Arbuckle (2001b) are among the few researchers who used HEPM in application to evaluate the impact of microfinance on borrower. They opined the limitation of selection bias, which seems difficult to evade even in quasi - experimental design. Dunn (2002) suggested a mixed method combining both survey and case study in applying HEPM in practice. The quasi-experimental method will be significant to overcome counterfactual issue. He also warned to be careful in choosing the control group in implementing the model. In this instance, the model is treated as quantitative impact evaluation model together with quasi-experimental design to find out microfinance impact. As a whole, this comprehensive model will give two categories of information. First, the magnitude and direction of the microfinance impact on borrowers in a quantitative aspect and second, the process through which this type of impact happens in a qualitative aspect. Another weakness of HEPM is self-reporting measure conducted in the survey (Dunn \& Arbuckle, 2001b; Jacobsen et al., 2006). It has not been possible to carry put a systematic check of the different variables self-reported by the borrower.

Alia, Ashta, and Ratsimalahelo (2017) considers HEPM Model by three complicating features to measure microfinance impact after summarizing the advantages and limitations of it. They found that the model delivered a good theoretical framework for tracing the flow of money and it overcame fungibility issue. However, this model intent to measure both economic and social impact on borrowers and it used self-reported methods since there were no formal records for impact measurement. Therefore, this model suffers from complexity related to two features. If complexity issues of these two features can be dealt with, this model can deliver a complete exhaustive measurement to evaluate microfinance impact. They suggested a modified version of HEPM after evaluating this model (Please 
see Figure 2). Through their suggested modifications, Alia et al. (2017) attempted to practice Modified-HEP to overcome these two limitations. For the diversity of impact, they recommended simplifying the HEP and for absence of formal record, they suggested using borrower diaries as an alternative of experiment. Many scientific researchers have used this diary method in their respective studies. It gives different type of data from other methods that are rich in quality. It also exposes the individual knowledge of the diarist on investigated matters. It gets attention for using diaries to explore continuing daily lives occasions to understand the truth of people's condition by capturing both quantitative and qualitative aspect of the researched topics from the beginning of twentieth century (Alia, Ashta and Zaka, 2013). The critics of financial diaries argue that financial diaries do not able to describe the dynamics of microfinance aimed at lessening poverty. The marginal poor people encounter three main difficulties related to financial portfolio such as lower level income, asymmetrical income and incapability for building bigger portfolios through savings ad borrowings. These have been dimensions of poverty observed through financial lens. Financial diaries display that marginal people try to manage their fund or resource but the portfolio they achieve are frequently fragile and incomplete. Hence, it is important to define how qualitative, elementary and simple financial services can be extended to these people on worldwide basis (Khandker, 2011).

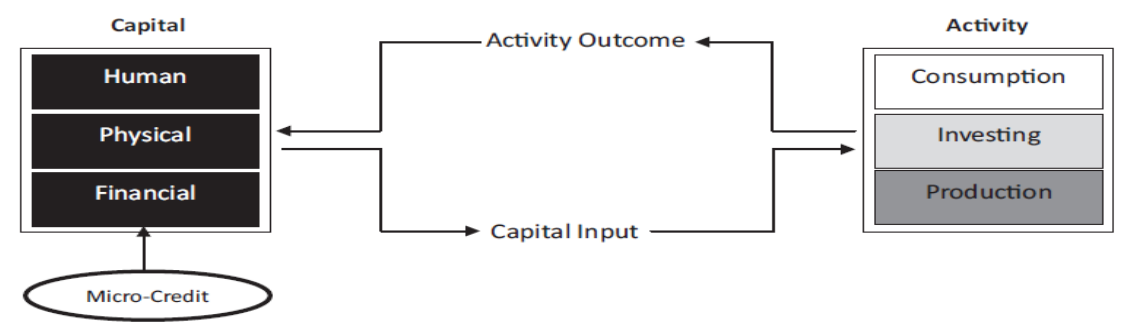

Figure 2. Modified HEPM (Alia et al., 2017)

It is very important to find out what happens among portfolio components. It can be done through two measures such as money and time to carry out the measurement. The physical and financial capital can be measured through money value. For instance, the question may be asked that how much monetary value has been invested or consumed. Though human capital is not easy to measure, only economic impact of this type of capital may be taken into consideration for measurement. Production activities are using human capital. Time is also required to utilize human capital factors like education, training, health intelligence etc. Time may be spent on sleeping, eating, cleaning etc. to maintain human capital. In another way, where investing or divesting physical or financial capital require money, time is required for investing or divesting human capital. Therefore, it can be suggested that time allocation on various activities can be used to find out economic value of human capital.

Activities can be tracked through the same two measures as previously mentioned, time and money. How much time has been spent can track both production and consumption activities. In the same way, how much money has been spent can track investing activities. Figure 3 shows the separation of components used in M-HEP.

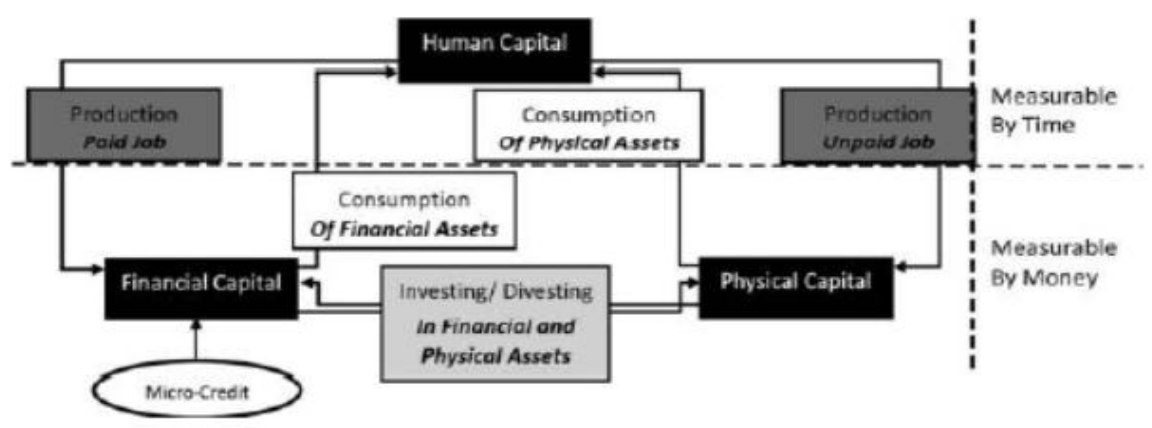

Figure 3. Measurement unit of M-HEPM (Alia et al., 2017) 
To account for both money and time, two types of diaries can be maintained to collect continuous information about what has been going on inside household portfolio. More specifically, financial diary can be used for money measure and activity diary can be used for time measure to have a comprehensive picture of the portfolio. In the methodology section, these two types of diary have been reviewed to see the process of changes of borrowers' lives for poverty alleviation by microfinance. Alia et al. (2017) study this type of process changes for poverty alleviation through a case study in Egypt. They have composed a financial diary reflecting borrower fund receipt \& payment and a activity diary reflecting borrower time use of different works for a poor woman in Egypt in August 2013 recorded both diaries for fourteen days written in Arabic.

\section{Qualitative Impact Assessment Methodology}

Some research methods appear to be superior to others subject to particular relevant research question. The option is not to choose one particular method but to choose combination with suitable mix. Quantitative method has been treated as a best alternative when researchers seek to have precise calculable changes over phenomena associated with or caused by particular intervention. On the other hand, qualitative method has been used to comprehend the process interacting together, more specifically when a direct causal relationship may not be untangled or become challenging to establish. A treatment group who gets treatment effect and a control group who does not, are the major theme of quantitative analysis. This type of analysis without involving quasi-experiments has been adopted since past twenty years in microfinance industry. But, these methods have certain weaknesses, mainly related to selection bias, as other researchers have noted in their studies (El-Zoghbi and Martinez, 2011).

With reference to previous section, Dunn (2002) suggested a mixed method in application of HEPM. He recommended combining survey with case study. Therefore, it becomes inclusive model by two kind of information. One is quantitative relating to size and direction and another is relating to process through which microfinance impact happens (E. Dunn, 2002). After evaluating HEPM, Alia et al. (2017) suggests a modified version of the model. They recommend using M-HEPM to overcome these two limitations - impact diversity and record lacking. For former one, they recommend simplifying HEP and for the latter one, they recommend using diaries instead of experiments. As per their suggestion, the microfinance impact can be evaluated from analyzing borrowers' dairy. Alia et al. (2017) did a case study on a single borrower name Sarah through financial and activity diaries showing two week period and analyzed her dairies for impact assessment through modified HEPM. Therefore, each borrower diary can be taken as a case study. In this research, we have taken ten diaries covering one-month period for experiment group (Participant borrowers who actively taken microfinance from GB by complying all the formalities) and control group (Non-participant borrowers who applied or desired microfinance from GB but could not get it for non-compliance of formalities) of GB borrowers. Although the number of diary considered in the studies is not enough to fetch statistical representation, the quality of the data is satisfying enough for understanding challenging conditions of the sampled respondent that deem to be similar to the conditions of millions of others in the country (Rutherford, 2003). Subsequently, we try to accumulate those case studies experience to conclude for impact of microfinance on borrowers qualitatively. Typical Financial Diary and Activity Diary have been given in Table 1 and Table 2 respectively for each case study of a borrower.

Table 1. Financial diary of a borrower

\begin{tabular}{lll}
\hline Date: & Receipt & \\
\hline Balanceb/d & Food & Payment \\
\hline Income & Cloths \\
\hline Loan & Medical \\
\hline Donation & Entertainment \\
\hline Other & Consumables \\
\hline & Saving \\
\hline & Refund \\
\hline & Other \\
\hline & Balance c/d
\end{tabular}


Table 2. Activity diary of a borrower

\begin{tabular}{|c|c|}
\hline Date: & \\
\hline Time & Daily Activity \\
\hline Hour 00.00 & \\
\hline Hour 01.00 & \\
\hline Hour 02.00 & \\
\hline Hour 03.00 & \\
\hline Hour 04.00 & \\
\hline Hour 05.00 & \\
\hline Hour 06.00 & \\
\hline Hour 07.00 & \\
\hline Hour 08.00 & \\
\hline Hour 09.00 & \\
\hline Hour 10.00 & \\
\hline Hour 11.00 & \\
\hline Hour 12.00 & \\
\hline Hour 13.00 & \\
\hline Hour 14.00 & \\
\hline Hour 15.00 & \\
\hline Hour 16.00 & \\
\hline Hour 17.00 & \\
\hline Hour 18.00 & \\
\hline Hour 19.00 & \\
\hline Hour 20.00 & \\
\hline Hour 21.00 & \\
\hline Hour 22.00 & \\
\hline Hour 23.00 & \\
\hline Hour 24.00 & \\
\hline
\end{tabular}

- Microfinance research by financial dairies: In microfinance research, David Hulme and Stuart Rutherford used financial diaries for the first time during 1999-2000 in Bangladesh. This helps to understand poor people financial needs and their economic practices in conducting lives. Each borrower needs to be visited once in a week for monitoring the daily transaction recorded in an optimum way and suggest correction if required. Borrowers need to write each transaction with date, value and purpose behind it. The quality of lives has been well-understood by this method although number of diarist borrowers is small (Rutherford, 2003). We can find whether poor borrowers have deserving financial lives and choice of decision-making. We also find focused income and expenditure categories to draw comprehensive outlook of the borrowers' livelihood. When borrowers are spending in building human, physical and financial capital, they are alleviating poverty or otherwise vice versa.

- Microfinance research by activity diaries: Several studies as discussed below related to poverty have used activity diary or alternatively time use diary. The household portfolio activities like production and consumption do not get enough research attention up until now. For measuring social and economic inter-household activities, especially through labor division, time use diary may provide useful information (Gammage, 2010). The well-being of the borrowers can be monitored through allocation of their respective time in various household activities. When we are assessing the poverty level, both time consumption and money consumption are valuable to make a conclusion (Bardasi \& Wodon, 2010). It is very important to differentiate between production-oriented (unpaid and paid job) and consumption-oriented (leisure and sports) time use (Burchardt, 2008). Goodin, Rice, Bittman, and Saunders (2005) deliberated outlining a time poverty line as a measure of time poverty in compare to income poverty line. There may 
be a minimum amount of time setting under which the borrowers can be considered time poor. We can define the measure of necessary time for necessary personal care time and necessary unpaid household labor time. Spending less time in the household's human capital is a sign of time poverty (Gammage, 2010). Studying time allocation in poverty-related research has been associated frequently with gender topics and the division of household labor and market labor time between female and male. Measuring microfinance impact on female borrowers should consider inter-household time spent by women between paid employment and nonpaid housework.

With the summary of time-use, activity diaries show why borrowers are poor. This has been obvious that poverty is resultant from lacking of paid work. We have classified the activities according to Maslow (1943)'s pyramid of needs as shown in Figure 4.

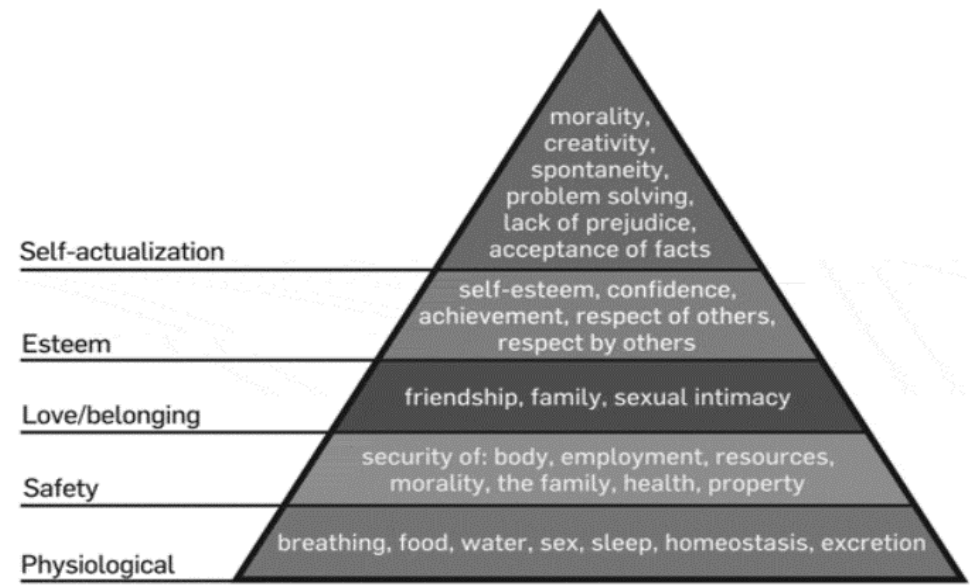

Figure 4. An interpretation of Maslow's hierarchy of needs (1943)

The level of poverty has been interpreted by which group the borrowers belong to. A borrower eventually become richer staring from physiological need (Category 1), then safety need (Category 2), then love/belonging need (Category 3), then esteem need (Category 4) and finally reach self-actualization need (Category 5) for ultimate destination. In another way, when borrowers are involved more in production activities and investing activities and/or less in consumption activities, they are also alleviating poverty. In addition, when borrowers spend more time in unpaid work, they are likely to fall below poverty level in longer period.

\section{Qualitative Impact Measurement Analysis}

Counterfactual problem occurs when we try to measure economic and social impact of microfinance in quantitative analysis. However, qualitative approach may be another way of explaining microfinance impact affecting lives of poor borrowers through detailed case studies. In this paper, we have applied modified HEPM for qualitative impact assessment for microfinance. This model overcome complexity limitations and also give solutions. It is simple and detailed with two types of diaries namely financial diary for fund receipt \& payment and activity dairy for time use in different activities of borrower. Investigating the information produced by these two diaries has not been easy but delivers quality information about borrowers' level of poverty as our case studies show.

\subsection{Financial Dairy Analysis}

- Participant borrowers: Borrowers usually do not seek to join alternative sources of finance besides borrowing solely from GB. One case out of ten gets micro loans from alternative sources. It means GB borrower appear to be provided sufficient loan to carry put their income generating works. They are not hungry to get more credit that save them from giving more time and effort because each borrowing source requires respective obligation for availing loans. They usually do not lose wages for complying formalities and obligations. Therefore, appropriate and flexible size of loans reduce physical and mental stress. A portion of borrowers' money goes towards servicing loan repayments and buying necessary items that serves quality of their lives. Borrowers do not need recycle their debts. Additionally, if we look at aggregate level, we find evidence that most borrowers' total income and expenditure do not fluctuate very much. They use the loan in productive purpose except a very few deviations. Many cases 
participant borrowers have been serving as a self-employed person in their respective working places. For this, they get revenue out of their work usually calculated monthly basis. They seldom do any job for others on daily or hourly basis. They are much more concentrated on their work mainly financed by GB.

- Non - Participant borrowers: Borrowers seek to join alternative sources of finance besides borrowing solely from GB. Four cases out of ten get small loans from other sources. It means the poor borrowers appear to be under provided in terms of the size of loan that they receive from any source. This hunger for extra credit requires borrowers not only to approach alternative borrowing sources, but also to make the loans expensive in terms of time and effort. Each borrowing source requires respective obligation for availing loans. The cost of attending formalities is higher as we find that several borrowers who are working have to lose a few hour's wages to attend those formalities and obligations. Therefore, making size of loans flexible and contingent on the risk profile of borrowers would reduce the need for physical and mental stress of managing money with multiple sources. A rather disturbing finding is the high proportion of some borrowers' money that goes towards servicing loan repayments. Several borrowers' fund has been spent on servicing existing loans and buying food items. Borrowers have little ability to spend under other budget categories such as health, education etc. Borrowers have been observed to recycle their debts to a substantial extent. We also observe that most of the major outflows that are followed by a major borrowing are on consumption items like jewelry, household accessories, etc. Additionally, if we look at aggregate level, we find evidence that most borrowers' total income exceeds their total expenditure plus loan repayment during this period. The fact reveals that some borrowings do not boost productive purpose use. Many cases non - participant borrowers have been serving as daily laborer in others working places. They usually do some jobs for others besides their main income generating works. Because their micro loans backed work are not sufficient enough to support them solely.

\subsection{Activity Dairy Analysis}

- Participant borrowers: Almost all participant borrowers in our case studies fulfill the physiological needs as per Abraham Maslow hierarchy theory. They also cover overall safety needs such as security of body, employment, resources, morality, family, health and property. For love or belonging, we cannot find the exact situation as they feel shy and not interested talking in details but it seems there are no major issues in this hierarchy need level. Initially, we found no activity for esteem hierarchy need. However, we were concerned by observing some of special behavior for different activities. In some cases, borrowers try to gain esteem through participating or organizing social events, giving some contribution in welfare activities or try to gain respect through art and culture. However, obviously it is very normal not to find the self-actualization need.

- Non - Participant borrowers: Non - participant borrowers in our case studies do not appear in a good position for satisfying all physiological needs. Majority cases do not cover basic needs or amenities like food, cloths, shelter, medicine and education. They are struggling to fulfill these needs at various levels. A few cases report to satisfy their safety needs. Actually in our case studies, we find non-participant borrowers as daily laborer without job security. They only get job on daily basis by their luck and sometimes through negotiation. Their jobs do not have consistent engagement by time or nature. They do whatever they find for their survival time to time. When they do not get the paid job, then they are sometimes involving for their households works for which they cannot pay. They also spend times in low coat entertainment like listing radio, watching nearby teal-stall television, taking indigenous sports, gossiping with fellow mates etc. Attending these types of activities usually in groups helps them to get the information if any job is available for them in surrounding areas. For love or belonging, we cannot find the exact situation as they feel shy and not interested talking in details but it seems there are no major issues in this hierarchy need level except some household quarrels or sometimes violence. There is very less symptom for esteem hierarchy need. However, we were concerned by observing some of special behavior for different activities. In some cases, borrowers try to gain esteem through participating or organizing social events, giving some contribution through small money or labor in welfare activities or try to gain respect through art and culture. Again, it is very normal not to find the self-actualization need.

\section{Conclusion}

In financial perspective, Participant borrowers get sufficient fund from and need not to seek alternative source. They can service loan repayments and buy necessary items that serve quality of their lives. They do not need recycle their debts and have stable income-expenditure pattern. They usually are self-employed persons and seldom do any job for others on daily or hourly basis. On the other hand, non-participant borrowers seek to join alternative sources of finance. This hunger for extra credit requires borrowers not only to approach alternative borrowing sources, but also to make the loans expensive in terms of time and effort. A potential risk is the high proportion of some borrowers' 
money goes towards servicing existing loan repayments. They have little ability to spend under food, health, education etc. Additionally, most borrowers' total income exceeds their total expenditure plus loan repayment and they have been serving as daily laborer.

In activity perspective, almost all participant borrowers fulfill the physiological needs and also cover overall safety needs. For love or belonging, the exact situation is not clear as they feel shy and not interested talking in details but it seems there are no major issues in this hierarchy need level. Borrowers try to gain esteem through participating or organizing social events. On the other hand, non - participant borrowers do not appear in a good position for satisfying all physiological needs. Majority cases do not cover basic needs or amenities. It is found that non-participant borrowers as daily laborer without job security. When they do not get the paid job, then they are sometimes involving for their households works for which they cannot pay. They also spend times in low coat entertainment like listing radio, watching nearby teal-stall television, taking indigenous sports, gossiping with fellow mates etc. For love or belonging is not clear from them although there is symptom of some household quarrels or sometimes violence. There is very less sign for esteem hierarchy satisfaction let alone self-actualization.

Therefore, it can be concluded that microfinance has positive impact of GB borrowers lives. It contributes to the favorable changes in their lives through financial discipline and activity pattern. The quality of lives can be achieved through using microfinance as poverty alleviation instrument. This qualitative analysis makes much more comprehensive impact on borrowers' lives rather only seeing the quantitative impact. This study includes only ten GB borrowers' diaries for the period of one month only. This type of studies can be extended through incorporating more and more case dairies for longer periods by pursuing borrowers to maintain financial and activity diaries instead of self-reporting usually happens in quantitative analysis. Only then, it will be possible to generalize the impact assessment results across sections and time periods all over the microfinance industry.

\section{Acknowledgements}

The authors are grateful to Universiti Malaysia Pahang and Ministry of Education Malaysia for supporting this research through Fundamental Research Grant Scheme (FRGS), grant number FRGS/1/2018/SS01/UMP/02/1 - RDU 190168.

\section{References}

Al Mamun, A., Abdul Wahab, S., \& Malarvizhi, C. (2011). Empirical investigation on repayment performance of Amanah Ikhtiar Malaysia's hardcore poor clients. International Journal of Business and Management, 6(7), 125-133. https://doi.org/10.5539/ijbm.v6n7p125

Al Mamun, A., Abdul Wahab, S., \& Malarvizhi, C. A. (2010). Impact of Amanah Ikhtiar Malaysia's microcredit schemes on microenterprise assets in Malaysia. International Research Journal of Finance and Economics, (60), 144-154. https://doi.org/10.2139/ssrn.1946089

Alia, H., Ashta, A., \& Ratsimalahelo, Z. (2017). A modified household economic portfolio model for assessing impact of microfinance using diaries. Qualitative Market Research: An International Journal, 20(1), 2-27. https://doi.org/10.1108/QMR-06-2016-0054

Alia, H., Ashta, A., \& Zaka, R. (2013, May 1). Time-Diary Research Method: Methodological Context, Evaluation and Applications in Academic Research. Evaluation and Applications in Academic Research. https://doi.org/10.2139/ssrn.2864381

Bardasi, E., \& Wodon, Q. (2010). Working long hours and having no choice: Time poverty in Guinea. Feminist Economics, 16(3), 45-78. https://doi.org/10.1080/13545701.2010.508574

Burchardt, T. (2008). Time and income poverty.

Cautero, R. M. (2019). What is Microfinance and Why Is It Important? The Balance - Banking and Loans. Retrieved from https://www.thebalance.com/what-is-microfinance-and-how-does-it-work-4165939

Chen, M., \& Dunn, E. (1996). Household economic portfolios, assessing the impact of microenterprise services (AIMS). Office of Microenterprise, USAID.

Coleman, B. E. (2002). Microfinance in Northeast Thailand: Who benefits and how much?. World Development, 34(9), 1612-1638. https://doi.org/10.1016/j.worlddev.2006.01.006

Dunn, \& Arbuckle. (2001a). The impacts of microcredit: a case study from Peru AIMS, USAID. Empowerment of Women.

Dunn, \& Arbuckle. (2001b). Microcredit and microenterprise performance: impact evidence from Peru. Small 
Enterprise Development, 12(4), 22-33. https://doi.org/10.3362/0957-1329.2001.043

Dunn, E. (2002). Research strategy for the AIMS core impact assessments. Washington, DC: AIMS.

Duvendack, M., Palmer-Jones, R., Copestake, J. G., Hooper, L., Loke, Y., \& Rao, N. (2011). What is the evidence of the impact of microfinance on the well-being of poor people?. In EPPI-Centre, Social Science Research Unit, Institute of Education.

El-Zoghbi, M., \& Martinez, M. (2011), Measuring Changes in Client Lives through Microfinance: Contributions of Different Approaches, Brief. CGAP, Washington, DC.

Gammage, S. (2010). Time pressed and time poor: unpaid household work in Guatemala. Feminist Economics, 16(3), 79-112. https://doi.org/10.1080/13545701.2010.498571

Gertler, P. J., Martinez, S., Premand, P., Rawlings, L. B., \& Vermeersch, C. M. (2016). Impact Evaluation in Practice. The World Bank. https://doi.org/10.1596/978-1-4648-0779-4

Gobezie, G., \& Garber, C. (2007). Impact assessment of microfinance in Amhara region of northern Ethiopia. Paper presented at the International Conference on Rural Finance Research: Moving Results into Policies, FAO, Rome, Italy.

Goodin, R. E., Rice, J. M., Bittman, M., \& Saunders, P. (2005). The time-pressure illusion: Discretionary time vs. free time. Social Indicators Research, 73(1), 43-70. https://doi.org/10.1007/s11205-004-4642-9

Hashemi, S. M., Schuler, S. R., \& Riley, A. P. (1996). Rural credit programs and women's empowerment in Bangladesh. World Development, 24(4), 635-653. https://doi.org/10.1016/0305-750X(95)00159-A

Hickel, J. (2015). The microfinance delusion: who really wins?. The Guardian, 10. Retrieved from https://www.theguardian.com/global-development-professionals-network/2015/jun/10/the-microfinance-delusio n-who-really-wins

Hulme, D. (1997). Impact assessment methodologies for microfinance: A review. AIMS, USAID.

Hulme, D. (2000). Impact assessment methodologies for microfinance: theory, experience and better practice. World Development, 28(1), 79-98. https://doi.org/10.1016/S0305-750X(99)00119-9

Husain, A. M. (1998). Poverty alleviation and empowerment: the second impact assessment study of BRAC's rural development programme. BRAC, Research and Evaluation Division.

Islam, T. (2007). Poverty alleviation impact on Grameen microcredit. Microcredit and Poverty Alleviation, 165-167.

Jacobsen, K., Marshak, A., Ofori-Adjei, A., \& Kembabazi, J. (2006). IDP Livelihoods: Using Microenterprise Interventions to Support the Livelihoods of Forcibly Displaced People: The Impact of a Microcredit Program in Idp Camps in Lira, Northern Uganda. Refugee Survey Quarterly, 25(2), 23-39. https://doi.org/10.1093/rsq/hdi0123

Khalily, M. B. (2004). Quantitative approach to impact analysis of microfinance programmes in Bangladesh-what have we learned?. Journal of International Development, 16(3), 331-353. https://doi.org/10.1002/jid.1081

Khandker, S. R. (1998). Micro-Credit Programme Evaluation: A Critical Review 1. IDS Bulletin, 29(4), 11-20. https://doi.org/10.1111/j.1759-5436.1998.mp29004002.x

Khandker, S. R. (2005). Microfinance and poverty: Evidence using panel data from Bangladesh. The World Bank Economic Review, 19(2), 263-286. https://doi.org/10.1093/wber/lhi008

Khandker, S. R. (2011). Book review: portfolios of the poor: how the world's poor live on \$2 a day. Economic Development \& Cultural Change, 60(2), 473-481. https://doi.org/10.1086/657131

MacIsaac, N. (1997). The role of microcredit in poverty reduction and promoting gender equity: A discussion paper. Report to CIDA.

Maslow, A. H. (1943). A theory of human motivation. Psychological Review, 50(4), 370. https://doi.org/10.1037/h0054346

Mosley, P. (2001). Microfinance and poverty in Bolivia. Journal of Development Studies, 37(4), 101-132. https://doi.org/10.1080/00220380412331322061

Pitt, M. M., \& Khandker, S. R. (1998). The impact of group-based credit programs on poor households in Bangladesh: Does the gender of participants matter?. Journal of Political Economy, 106(5), 958-996. https://doi.org/10.1086/250037 
Rutherford, S. (2003). Money talks: Conversations with poor households in Bangladesh about managing money. Journal of Microfinance/ESR Review, 5(2), 4.

Taylor, M. (2011). 'Freedom from poverty is not for free': rural development and the microfinance crisis in Andhra Pradesh, India. Journal of Agrarian Change, 11(4), 484-504. https://doi.org/10.1111/j.1471-0366.2011.00330.x

TRT World. (2017). Roundtable: Does Microfinance empower or impoverish. Retrieved from https://www.youtube.com/watch?v=U_lgCLmvRQo\&t=946s

Zaman, H. (1999). Assessing the poverty and vulnerability impact of micro-credit in Bangladesh: A case study of $B R A C$. World Bank, Development Economics, office of the Senior Vice President. 